\title{
Effective and Meaningful Online Learning in the Covid-19 Pandemic: Best Practice in Integrating Local Culture in EFL
}

\author{
Ni Made Ratminingsih ${ }^{1}$, I Ketut Trika Adi Ana ${ }^{1}$, I Gede Budasi ${ }^{1}$, Ketut Agustini ${ }^{2}$ \\ English Education Department, Ganesha University of Education, J1. A. Yani, No. 67, Singaraja, Bali \\ Indonesia ${ }^{1}$, Informatics Engineering Education Department, Ganesha University of Education, Jl. \\ Udayana No. 11, Singaraja, Bali, Indonesia ${ }^{2}$ \\ \{made.ratminingsih@undihsha.ac.id\}
}

\begin{abstract}
The Covid-19 pandemic forces teachers to apply distance learning through online. In online learning, technology is only a tool, and its success is influenced by how that technology is used. This indicates that pedagogical knowledge is the foundation that makes online learning successful. Therefore, this paper aims to explain strategies for effective and meaningful online learning, especially in English as a foreign language (EFL) context, which promotes local culture. This paper is written based on a systematic literature review and best practices on implementing online learning in the Covid-19 pandemic. It starts with the concept of effective and meaningful learning. Then, it specifically discusses the concepts of teaching EFL, what to learn in EFL, and the interconnection of language and culture in the EFL context. Finally, it provides a method of best practices to conduct online learning for teaching EFL during the Covid-19 pandemic.
\end{abstract}

Keywords: effective and meaningful learning; language and culture; online learning

\section{Introduction}

Learning is generally a process of obtaining new information or knowledge and skill delivered by teachers. It is an interactional educative process that is bound with objectives [1]. There are three features of learning, namely (1) it is an active process in which the learner relates the new experience to existing meaning and may accommodate and assimilate new ideas, (2) past, present, and future are connected, and (3) the process is influenced by the use of how the learning is actualized in the future [2]. It is a process of how the learners get a new knowledge or skill and make use of those knowledge, skill, attitude and behaviour in a meaningful way to enhance problem solving skills and to do things independently [3], [4]. In addition, learning is a never-ending process of self-actualization that should always develop [5]. From those explanations, it is clear that learning is an active interactional educative process. It connects prior knowledge and skill with existing knowledge and skill to form new knowledge and skill to attain learning objectives and how it is used in the future.

In learning, learners are given materials using certain relevant methods and techniques of teaching and learning with the support of facilities and learning media to reach the objectives. To reach optimum and conducive learning, teachers are required to select the materials, determined appropriate teaching and learning strategies that are supported with sufficient learning media that help learners maximize their learning [1]. In other words, to run an effective 
learning, teachers should prepare their instruction well [6], [7]. Furthermore, the extent to which the learning reaches the instructional objectives can be seen from a set of evaluations. Thus, it signifies that optimum or effective learning happens when there is a successful attainment of objectives shown from the result of assessments.

Meaningful learning simply means that what learners are learning and have learned has meaning to their real life. It refers to learning the materials connected to learners' daily lives [8]. The context of their daily life or environment should be brought into the classroom. By doing so, they learn things related to their lives, which will be used in their lives. Contextual learning is the learning which relates the materials with the real-life, including family, community, and environment, that help them see the connection of what they learn with its application in their real world [9]. Contextual learning could increase the learners' interest in learning and is more effective in improving their skills [10]. Therefore, it can be emphasized that contextual learning is the learning which brings the context of real-life into the learning materials. It becomes meaningful because what they learn is connected to their real life. Thus, it is interesting, and as a consequence, it gives an effect to their maximum learning.

The Covid-19 pandemic is a new challenge for the teachers in conducting the teaching and learning process. This pandemic forces the teachers to shift their teaching mode from face-toface instruction to online learning [11]. Many studies claimed that the use of technology in the classroom could enhance the quality of the instruction [12]-[14]. However, the case is quite different during the Covid-19 pandemic, where the instruction should be conducted fully online without any specific preparation. This sudden change causes many problems in the instructional process for both the students and the teachers [15], [16]. Several studies found that many teachers and students were not ready with online learning. Some reported that the senior teachers, especially the $\mathrm{X}$ generation, were struggling with the technology for conducting online learning [17]-[20]. In addition, the other studies found that both the students and teachers in developing countries normally had problems with reliable internet connections, so that they cannot use sophisticated learning management systems [21], [22]. The implementation of online learning should be supported by the teachers', students', and infrastructure readiness [23], [24]. Thus, considering the reality of online learning during the Covid-19 pandemic, it was difficult to make online learning to be effective and meaningful learning.

This paper aims to elaborate further on the nature of effective and meaningful learning, what to learn in EFL, language and culture in EFL context, technology in EFL online learning, and best practice of EFL through online learning.

\section{Research Methods}

This study is classified into a literature review. Specifically, the writers followed the systematic literature review method that consisted of four steps. Those steps were designing the review, conducting the review, analysing, and writing the review [25]. The data of this study were collected from books and scientific articles published in national and international journals. Since the articles were collected from the electronic journals, the researchers used specific keywords in finding the articles and used some specific criteria to select the articles. Those criteria include the year of the publication, the topic, and the indexed status of the publication. The books and articles should be published around the years 2011 to 2021. The books and articles should discuss effective and meaningful learning, students' culture in the EFL context, and best teaching practices during the Covid-19 pandemic. 
While for the indexed criteria, the journals should be indexed by Sinta, Scopus, or Web of Science. The collected data were analysed qualitatively using the interactive data analysis model by Miles et al. (2014). This data analysis model consisted of three steps: data reduction, data display, and conclusion drawing/verification.

\section{Results and Discussion}

\subsection{Effective and Meaningful Learning}

Effective means that the knowledge learned has an effect. The effectiveness can be seen from the achievement of the objectives and the potency of knowledge use in the long run. The teacher is the key element in creating effective learning [27]. The effectiveness of the instruction lies on the teachers' pedagogical competence [28] [29].

Meaningful learning is a learning method in which new knowledge to be learned is related to prior knowledge [30]. Meaningful learning happens if the learners are involved in selecting, organizing, and integrating in a coordinated way to make sense of the presented material [31]. Common characteristics of meaningful learning include active, authentic, constructive, cooperative, and personalized [32]. Meaningful learning can be promoted by lowering cognitive load while enhancing generative processing [33].

Creating meaningful learning through multimedia learning should combine behavioral and cognitive activities [34], [35]. Thus, in online learning, meaningful learning experiences can be promoted by connecting the online discussion to the other resources available on the internet or the students' live experiences [36].

\subsection{What to Learn in EFL}

In general, four language skills should be mastered in learning a language. Those four language skills are listening, speaking, reading, and writing [37]. Speaking and writing skills are productive skills, while listening and reading are considered passive skills [38]. All of those language skills are important for the learners on EFL, and each of those skills has its difficulties for the learners. In learning English as a foreign language, those four language skills can be learned separately or simultaneously in an integrated way. Besides the four language skills, there are also some language elements that the students need to learn. They are the vocabulary, pronunciation, and grammar of the target language [39]. They are the foundation of language skills.

\subsection{Language and Culture in EFL Context}

Language is a part of the human culture. Thus, learning a language cannot be separated from learning its culture [40]. The previous concept of learning EFL suggests that the students have to learn the target language and its culture [41], [42]. Thus, authentic materials which are taken from the real communication of the English native speakers are highly recommended to be used during the teaching and learning process [43]. Then, it moves to cross-cultural understanding, which means both the student's culture and the target language should be introduced to build cultural awareness [44], [45]. Cross-cultural understanding in the EFL context is crucial for the learners to help them become intercultural beings [46], [47].

In addition, the importance of intercultural understanding has something to do with the status of English that becomes a lingua franca where the number of English users is more than the number of its native speakers [48]. It means that English has become a global language that 
unites people around the globe to be global citizens [48], [49]. Thus, education should promote both the national and international culture to prepare the students to become global citizens with a profound cross cultural understanding [50]-[52]. The development of the concept in integrating culture in EFL is presented in Figure 1 below.

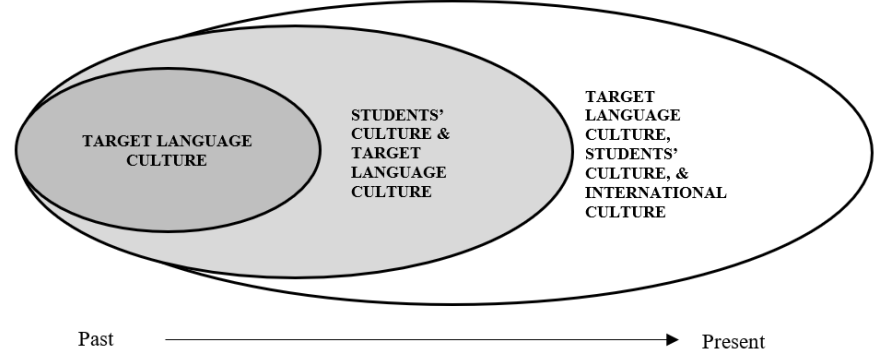

Fig. 1. The development of the concept in integrating culture in EFL.

Considering the EFL class condition in Indonesia, dealing with a cultural aspect, teachers may start by introducing learning materials that integrate the students' culture first. When their English proficiency is getting better, more English materials with target language culture and international culture may be introduced without neglecting the students' culture. The use of learning materials with the students' culture will help the students to learn English better and easier when the students are at a beginner level. Integrating their indigenous culture in the learning material will activate their prior knowledge on the topic they are studying. Building students' prior knowledge is important in the EFL context because it will help them understand the learning material better and improve their language skills [53], [54].

However, when their English proficiency is getting better, they should learn the target language and international culture to become global citizens. It is because, nowadays, English is already a global language or lingua franca [55], [56]. The suggested stages in integrating cultural content in EFL learning materials are described in Figure 2.

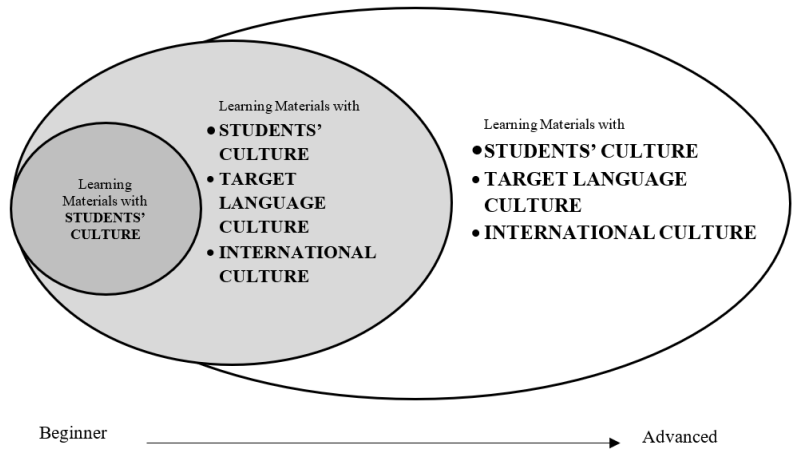

Fig 2. The Suggested Stages in Integrating Cultural Content in EFL Learning Materials.

\section{Technology in EFL Online Learning}

Technology has been pervasively used in the teaching and learning process since the Covid-19 pandemic outbreak. The use of technology in this situation brings the advantage that it keeps the learning going on though it is done from homes. It makes learning more flexible, which can be done in different places and unlimited time. Allen and Seaman [57] defined learning through technology as online learning, that is a learning process that takes place through the internet. Through internet access, there are several tools for developing and delivering materials that can be easily applied. This allows users to operate the teaching and learning 
environment more flexibly [15]. Technology in the education field has some advantages, such as the students can acquire the knowledge and information quickly [58]. It also helps them practice more on their ability to collect the information from many sources. Thus, the existence of the internet and technology is very helpful and supports the online learning process [59], [60].

Furthermore, specifically on the use of online learning in EFL, some studies also have proven that online learning have some advantages. In this digital era, most of the EFL students have a positive attitude toward the implementation of online learning [61], [62]. For the students, online learning with various materials and strategies makes the EFL teaching and learning process interesting [63]. In terms of the students' achievement on language skills and language elements, some studies also confirmed that the use of online learning could help the students to improve their competence in those language skills and elements [64]-[67]. However, technology is merely a tool that helps the teachers deliver the instruction. The effectiveness is not influenced by what technology is used but how the technology is used by the teachers [68]. Thus, to create meaningful learning, teachers should make sure that they equip themselves with appropriate teaching strategies in conducting online learning.

\section{Best Practice of EFL through Online Learning}

Several aspects need to be taken into account when it comes to the implementation of online learning. Those aspects include teachers' technological pedagogical competence, teachers' attitude toward the use of technology in education, and the infrastructure that support the implementation of online learning [20], [69]-[71]. The pedagogical aspect is very important in delivering online learning. Technology is only a tool. How the teachers use the technology is the one that matters in conducting effective learning [58]. Thus, technological pedagogical and content knowledge (TPACK) becomes a must in ensuring online learning success [72], [73]. However, not all teachers in Indonesia have good technological pedagogical competence [6]. That situation influences the teachers' attitude toward the implementation of technology. Since integrating technology is difficult for some teachers, they have a negative attitude toward using technology in the learning process [74]. In addition, the lack of infrastructure also creates another challenge for the teachers to conduct online learning in Indonesia [75], [76].

Therefore, teachers need a simple technology that can be used easily without any specific training to solve those problems. If teachers believe that using technology is not difficult, it may build their positive attitude on implementing technology. In addition, the technology should not require specific infrastructure so all teachers can use them. Thus, based on the writers' experience in delivering online learning during the Covid-19 pandemic, the writers proposed to use simple and user-friendly media and the MAHA ESA method to deliver online instruction. This method was inspired by flipped learning approach [77], and the steps of the MAHA ESA method can be seen in Table 1 .

Table 1. MAHA ESA Method.

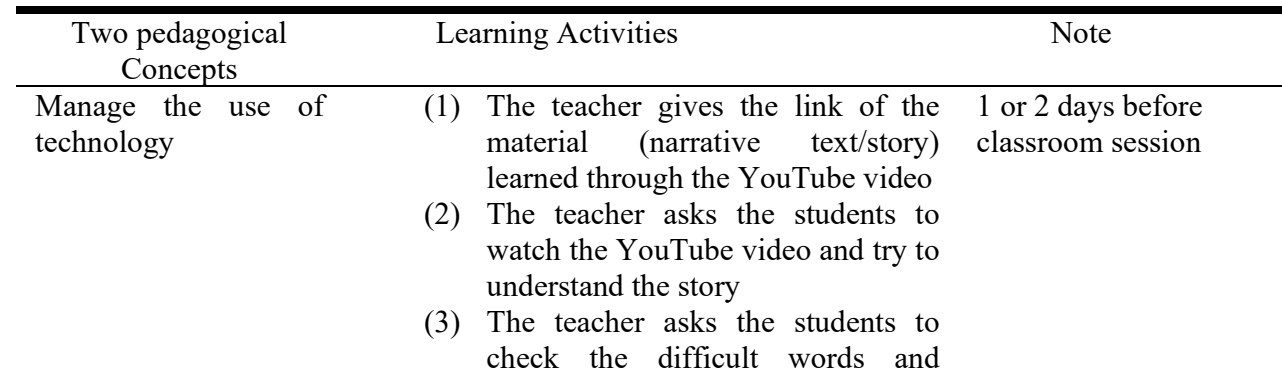




\begin{tabular}{|c|c|c|}
\hline & $\begin{array}{l}\text { pronunciations of words using } \\
\text { Google Translate }\end{array}$ & \\
\hline Accelerate & $\begin{array}{l}\text { The teacher provides questions to answer } \\
\text { through WhatsApp or Google Classroom }\end{array}$ & $\begin{array}{l}1 \text { or } 2 \text { days before } \\
\text { classroom session }\end{array}$ \\
\hline Help & $\begin{array}{l}\text { The students ask what they don't understand } \\
\text { through WhatsApp or Google Classroom. }\end{array}$ & $\begin{array}{l}\text { Before and during the } \\
\text { classroom session }\end{array}$ \\
\hline Acquire & $\begin{array}{l}\text { (1) Students answer the questions given by } \\
\text { the teacher individually in written form. } \\
\text { (2) Students answer the questions } \\
\text { interactively through dialogic } \\
\text { reading/listening through Google meet or } \\
\text { WhatsApp. }\end{array}$ & $\begin{array}{l}\text { Before classroom } \\
\text { session } \\
\text { During classroom } \\
\text { session }\end{array}$ \\
\hline Engage & $\begin{array}{l}\text { (1) Students are engaged in fun learning } \\
\text { through YouTube video } \\
\text { (2) Students are involved in communicating } \\
\text { between teacher and students through } \\
\text { Google meet or WhatsApp (voice notes } \\
\text { or typing) }\end{array}$ & $\begin{array}{l}\text { Before classroom } \\
\text { session } \\
\text { During classroom } \\
\text { session }\end{array}$ \\
\hline Study & $\begin{array}{l}\text { (1) Students study the material (narrative } \\
\text { text/story) through YouTube video } \\
\text { (2) Students learn through dialogic } \\
\text { Reading/Listening through Google meet } \\
\text { or WhatsApp (voice notes or typing) }\end{array}$ & $\begin{array}{l}\text { Before classroom } \\
\text { session } \\
\text { During classroom } \\
\text { session }\end{array}$ \\
\hline Activate & $\begin{array}{l}\text { (1) Students retell the text (story) in } 3 \text { to } 5 \\
\text { sentences (speaking) through Google } \\
\text { meet or WhatsApp (voice notes or } \\
\text { typing) } \\
\text { (2) Students write the summary of the text } \\
\text { (story) in } 3 \text { up to } 5 \text { sentences and submit } \\
\text { their work through WhatsApp or Google } \\
\text { Classroom. }\end{array}$ & $\begin{array}{l}\text { During classroom } \\
\text { session }\end{array}$ \\
\hline
\end{tabular}

If we see from the five characteristics of meaningful learning that consists of active, authentic, constructive, cooperative, and personalized [32], those activities in Table 1 can be explained as follows.

\section{Active}

The activities in the MAHA ESA method activate the students to involve during the teaching and learning process. It can be seen from the activities during the help, acquire, engage, study, and activate steps. Those activities show that the instruction is conducted through a student-centered approach. In addition, those activities provide the students with opportunities to build their understanding. In other words, the activities are in line with active learning, i.e., guiding the students to be actively involved in the learning process to create their own understanding of the subject they are studying [78]. Thus, the result of active learning relies on the quality of the inquiry process [79].

2. Authentic

The authentic part can be seen from the teaching and learning process materials that integrate the students' culture. The materials were made in videos and delivered through social media (YouTube). In the MAHA ESA method, the use of authentic materials can be seen in the step of manage of the use of technology activities. The content of the learning materials that contain the authentic culture of the students will help the students build their prior knowledge 
on the topic they are studying. This prior knowledge will help them understand the materials easier [80]. Besides, using authentic materials can help students be more active during the instructional process [81].

3. Constructive

Constructive learning can be defined as a method to activate students' participation in constructing their knowledge [82]. This concept overlaps with active learning since in constructing their own knowledge, they have to be active learners. Specifically, for the constructive process, in the MAHA ESA method, the activities have been started from the stage of manage the use of technology activities. Then it is strengthened in the stages of acquire, engage, and activate activities. All of those activities guide the students to construct their own knowledge.

4. Cooperative

Cooperative learning is a teaching strategy that involves small teams and uses various learning activities to improve their understanding of a subject [83]. Social media can be used as an alternative application to conduct effective cooperative learning since the students are familiar with the social media application, and social media facilities which support cooperative learning implementation [84]. For example, it provides a group chat facility. In the MAHA ESA method, the cooperative activities are done in the engage activities to discuss their task.

5. Personalized

Personalized learning is an educational approach that aims to customize learning for each student's strengths, needs, skills, and interests [85]. In the MAHA ESA method, the students have their control over their learning. For instance, in the step of manage the use of technology, the students are free to explore the materials given and to use any online tools that can help them to understand the material better. Personalized learning is one of the online learning strengths, because in online learning the teachers can set a chance for the students to learn the materials on their learning style [86]-[88]

\section{Conclusion}

This paper concludes some important points. First, integrating technology in the teaching and learning process will positively affect the students to achieve a maximum learning when the teachers can apply the technology properly. Since not all teachers have good competence in using sophisticated educational technology, a simple and user-friendly technology like social media can be used as an alternative technology to conduct online learning. Second, in the EFL context, besides technology, culture also becomes a fundamental issue since language cannot be separated from culture.

However, it is suggested that the integration of cultural knowledge should be started with the students' culture for EFL learners. As their English proficiency is getting better, more target language cultures need to be introduced, as well as the international cultures. Third, the MAHA ESA method can be used as an alternative way to conduct an effective and meaningful online learning. Since this paper is written through a systematic literature review method, a profound study that evaluates the effectiveness of social media, students' cultural knowledge, and the MAHA ESA method to create meaningful online learning needs to be conducted. 


\section{Acknowledgments}

The authors are highly indebted to the Directorate of Resources, Director General of Higher Education for the trust and fund granted to conduct the research and great appreciation is also forwarded to the Rector and Head of LPPM of Universitas Pendidikan Ganesha (Undiksha) for their endless support to expedite the accomplishment of the research. We hope that it can give valuable knowledge for the interested readers in the relevant field of study.

\section{References}

[1] I. W. Suastra, Pembelajaran sains terkini. Singaraja: Universitas Pendidikan Ganesha, 2017.

[2] C. Watkins, E. Carnell, C. Lodge, P. Wagner, and C. Whalley, "Effective learning," Res. Matters, vol. 17, pp. 1-8, 2014, doi: 10.4324/9781315517933-29.

[3] [3] D. Thompson, M. Leach, C. Smith, J. Fereday, and E. May, "How nurses and other health professionals use learning principles in parent education practice: A scoping review of the literature," Heliyon, vol. 6, no. 3, p. e03564, 2020, doi: https://doi.org/10.1016/j.heliyon.2020.e03564.

[4] G. K. Nithyanandam, "A framework to improve the quality of teaching-learning process - A case study," Procedia Comput. Sci., vol. 172, no. 2013, pp. 92-97, 2020, doi: 10.1016/j.procs.2020.05.013.

[5] T. A. Tsimane and C. Downing, "Transformative learning in nursing education: A concept analysis," Int. J. Nurs. Sci., vol. 7, no. 1, pp. 91-98, 2020, doi: https://doi.org/10.1016/j.ijnss.2019.12.006.

[6] E. Munastiwi and S. Puryono, "Unprepared management decreases education performance in kindergartens during Covid-19 pandemic," Heliyon, vol. 7, no. 5, p. e07138, 2021, doi: https://doi.org/10.1016/j.heliyon.2021.e07138.

[7] K. Contreras, C. Arredondo, C. Díaz, M. J. Inostroza, and B. Strickland, "Examining differences between pre- and in-service teachers' cognition when lesson planning," System, vol. 91, p. 102240, 2020, doi: https://doi.org/10.1016/j.system.2020.102240.

[8] N. M. Ratminingsih, I. G. Budasi, and W. D. A. Kurnia, "Local culture-based storybook and its effect on reading competence," Int. J. Instr., vol. 13, no. 2, pp. 253-268, 2020, doi: 10.29333/iji.2020.13218a.

[9] D. D. Samo, K. Darhim, and B. G, "Culture-based contextual learning to increase problem-solving ability of first year university student," J. Math. Educ., vol. 9, no. 1, pp. 81-94, 2018.

[10] I. Satriani and E. Emilia, "Contextual teaching and learning approach to teaching writing.Indonesian," J. Appl. Linguist., vol. 2, no. 1, pp. 10-22, 2012.

[11] M. Daumiller, R. Rinas, J. Hein, S. Janke, O. Dickhäuser, and M. Dresel, "Shifting from face-to-face to online teaching during COVID-19: The role of university faculty achievement goals for attitudes towards this sudden change, and their relevance for burnout/engagement and student evaluations of teaching quality," Comput. Human Behav., vol. 118, p. 106677, 2021, doi: https://doi.org/10.1016/j.chb.2020.106677.

[12] M. Z. M. Zin, A. A. Sakat, N. A. Ahmad, and A. Bhari, "Relationship Between the Multimedia Technology and Education in Improving Learning Quality," Procedia - Soc. Behav. Sci., vol. 90, pp. 351-355, 2013, doi: https://doi.org/10.1016/j.sbspro.2013.07.102.

[13] M. T. Al-Hariri and A. A. Al-Hattami, "Impact of students' use of technology on their learning achievements in physiology courses at the University of Dammam,” J. Taibah Univ. Med. Sci., vol. 12, no. 1, pp. 82-85, 2017, doi: https://doi.org/10.1016/j.jtumed.2016.07.004.

[14] B. Piper, S. S. Zuilkowski, D. Kwayumba, and C. Strigel, "Does technology improve reading outcomes? Comparing the effectiveness and cost-effectiveness of ICT interventions for early grade reading in Kenya," Int. J. Educ. Dev., vol. 49, pp. 204-214, 2016, doi: https://doi.org/10.1016/j.ijedudev.2016.03.006.

[15] T. Muthuprasad, S. Aiswarya, K. S. Aditya, and G. K. Jha, "Students' perception and preference for online education in India during COVID -19 pandemic," Soc. Sci. Humanit. Open, vol. 3, no. 1, p. 100101, 2021, doi: https://doi.org/10.1016/j.ssaho.2020.100101. 
[16] A. Selvaraj, V. Radhin, N. KA, N. Benson, and A. J. Mathew, "Effect of pandemic based online education on teaching and learning system," Int. J. Educ. Dev., vol. 85, p. 102444, 2021, doi: https://doi.org/10.1016/j.ijedudev.2021.102444.

[17] L. Mishra, T. Gupta, and A. Shree, "Online teaching-learning in higher education during lockdown period of COVID-19 pandemic," Int. J. Educ. Res. Open, vol. 1, p. 100012, 2020, doi: https://doi.org/10.1016/j.ijedro.2020.100012.

[18] C. Damşa, M. Langford, D. Uehara, and R. Scherer, “Teachers' agency and online education in times of crisis," Comput. Human Behav., vol. 121, p. 106793, 2021, doi: https://doi.org/10.1016/j.chb.2021.106793.

[19] S. Abuhammad, "Barriers to distance learning during the COVID-19 outbreak: A qualitative review from parents' perspective," Heliyon, vol. 6, no. 11, p. e05482, 2020, doi: https://doi.org/10.1016/j.heliyon.2020.e05482.

[20] R. Scherer, S. K. Howard, J. Tondeur, and F. Siddiq, "Profiling teachers' readiness for online teaching and learning in higher education: Who's ready?," Comput. Human Behav., vol. 118, p. 106675, 2021, doi: https://doi.org/10.1016/j.chb.2020.106675.

[21] O. B. Azubuike, O. Adegboye, and H. Quadri, "Who gets to learn in a pandemic? Exploring the digital divide in remote learning during the COVID-19 pandemic in Nigeria," Int. J. Educ. Res. Open, vol. 2-2, p. 100022, 2021, doi: https://doi.org/10.1016/j.ijedro.2020.100022.

[22] A. Elzainy, A. El Sadik, and W. Al Abdulmonem, "Experience of e-learning and online assessment during the COVID-19 pandemic at the College of Medicine, Qassim University," J. Taibah Univ. Med. Sci., vol. 15, no. 6, pp. 456-462, 2020, doi: https://doi.org/10.1016/j.jtumed.2020.09.005.

[23] A. A. Afolabi, "Availability of Online Learning Tools and the Readiness of Teachers and Students towards it in Adekunle Ajasin University, Akungba-akoko, Ondo State, Nigeria," Procedia - Soc. Behav. Sci., vol. 176, pp. 610-615, 2015, doi: 10.1016/j.sbspro.2015.01.517.

[24] M. Coopasami, S. Knight, and M. Pete, "e-Learning readiness amongst nursing students at the Durban University of Technology," Heal. SA Gesondheid, vol. 22, pp. 300-306, 2017, doi: https://doi.org/10.1016/j.hsag.2017.04.003.

[25] H. Snyder, "Literature review as a research methodology: An overview and guidelines," J. Bus. Res., vol. 104, no. July, pp. 333-339, 2019, doi: 10.1016/j.jbusres.2019.07.039.

[26] M. B. Miles, A. M. Huberman, and J. Saldaña, Qualitative Data Analysis, 3rd Editio. London: SAGE Publication, 2014

[27] C. L. Oprea, "The Enthusiastic Teaching-The Actor's Art Didactically Transposed for Teachers," Procedia - Soc. Behav. Sci., vol. 76, pp. 602-607, 2013, doi: 10.1016/j.sbspro.2013.04.172.

[28] L. Mâţă, D. Cmeciu, and R. M. Ghiaţău, "A Reference Framework of Pedagogical Competences of Language Teachers in the Initial Training Programmes," Procedia - Soc. Behav. Sci., vol. 93, pp. 648-653, 2013, doi: 10.1016/j.sbspro.2013.09.255.

[29] S. J. Prameswari and C. Budiyanto, "The development of the effective learning environment by creating an effective teaching in the classroom.," IJIE (Indonesian J. Informatics Educ., vol. 1, no. 1, pp. 79-86, 2017, doi: 10.20961/ijie.v1i1.11960.

[30] P. Chan, S. Kim, L. Garavalia, and J. Wang, "Implementing a strategy for promoting long-term meaningful learning in a pharmacokinetics course," Curr. Pharm. Teach. Learn., vol. 10, no. 8, pp. 1048-1054, 2018, doi: https://doi.org/10.1016/j.cptl.2018.05.013.

[31] R. E. Mayer, "Chapter Three - Applying the Science of Learning to Multimedia Instruction," vol. 55, J. P. Mestre and B. H. B. T.-P. of L. and M. Ross, Eds. Academic Press, 2011, pp. 77-108.

[32] Y.-M. Huang and P.-S. Chiu, "The effectiveness of the meaningful learning-based evaluation for different achieving students in a ubiquitous learning context," Comput. Educ., vol. 87, pp. 243-253, 2015, doi: https://doi.org/10.1016/j.compedu.2015.06.009.

[33] A. T. Stull, M. J. Gainer, and M. Hegarty, "Learning by enacting: The role of embodiment in chemistry education," Learn. Instr., vol. 55, pp. 80-92, 2018, doi: https://doi.org/10.1016/j.learninstruc.2017.09.008.

[34] I. T. Skuballa, A. Dammert, and A. Renkl, "Two kinds of meaningful multimedia learning: Is cognitive activity alone as good as combined behavioral and cognitive activity?," Learn. Instr., vol. 54, pp. 35-46, 2018, doi: https://doi.org/10.1016/j.learninstruc.2018.02.001. 
[35] L. A. Cárdenas-Robledo and A. Peña-Ayala, "Ubiquitous learning: A systematic review," Telemat. Informatics, vol. 35, no. 5, pp. 1097-1132, 2018, doi: https://doi.org/10.1016/j.tele.2018.01.009.

[36] S. A. Aderibigbe, "Can online discussions facilitate deep learning for students in General Education?," Heliyon, vol. 7, no. 3, p. e06414, 2021, doi: https://doi.org/10.1016/j.heliyon.2021.e06414.

[37] J. Masuram and P. N. Sripada, "Developing spoken fluency through task-based teaching," Procedia Comput. Sci., vol. 172, pp. 623-630, 2020, doi: https://doi.org/10.1016/j.procs.2020.05.080.

[38] D. Golkova and S. Hubackova, "Productive Skills in Second Language Learning," Procedia - Soc. Behav. Sci., vol. 143, pp. 477-481, 2014, doi: 10.1016/j.sbspro.2014.07.520.

[39] S. BaLatur, "The Perceptions of EFL Prep School Students on their Listening Skills: A Quantitative Study," Procedia - Soc. Behav. Sci., vol. 232, no. April, pp. 806-812, 2016, doi: 10.1016/j.sbspro.2016.10.109.

[40] A. V. Baydak, C. Scharioth, and I. A. Il'yashenko, "Interaction of Language and Culture in the Process of International Education,” Procedia - Soc. Behav. Sci., vol. 215, no. June, pp. 14-18, 2015, doi: 10.1016/j.sbspro.2015.11.567.

[41] Z. Tavakkoli and M. Moradishad, "Cultural Exposure and Language Proficiency of Iranian EFL Learners," Procedia - Soc. Behav. Sci., vol. 98, pp. 2035-2044, 2014, doi: https://doi.org/10.1016/j.sbspro.2014.04.376.

[42] G. Tüm and S. Uğuz, "An Investigation on the Cultural Elements in a Turkish Textbook for Foreigners," Procedia - Soc. Behav. Sci., vol. 158, pp. 356-363, 2014, doi: https://doi.org/10.1016/j.sbspro.2014.12.100.

[43] E. Kozhevnikova, "Exposing Students to Authentic Materials as a Way to Increase Students' Language Proficiency and Cultural Awareness," Procedia - Soc. Behav. Sci., vol. 116, pp. 4462 4466, 2014, doi: 10.1016/j.sbspro.2014.01.967.

[44] M. T. Yeganeh and H. Raeesi, "Developing Cultural Awareness in EFL Classrooms at Secondary School Level in an Iranian Educational Context," Procedia - Soc. Behav. Sci., vol. 192, pp. 534-542, 2015, doi: https://doi.org/10.1016/j.sbspro.2015.06.084.

[45] A. Habók, Y. Kong, J. Ragchaa, and A. Magyar, "Cross-cultural differences in foreign language learning strategy preferences among Hungarian, Chinese and Mongolian University students," Heliyon, vol. 7, no. 3, p. e06505, 2021, doi: https://doi.org/10.1016/j.heliyon.2021.e06505.

[46] E. A. Damar, "Culture: Is it an Avoidable or Adorable Concept in EFL Settings?," Procedia - Soc. Behav. Sci., vol. 93, pp. 752-755, 2013, doi: https://doi.org/10.1016/j.sbspro.2013.09.275.

[47] ÿzlem K. Tuna and S. Raz1, "Integrating Culture into ELT Classes: What, Why, and How?," Procedia - Soc. Behav. Sci., vol. 232, pp. 41-48, 2016, doi: https://doi.org/10.1016/j.sbspro.2016.10.009.

[48] I.-C. Ke and H. Cahyani, "Learning to become users of English as a Lingua Franca (ELF): How ELF online communication affects Taiwanese learners' beliefs of English," System, vol. 46, pp. 28-38, 2014, doi: https://doi.org/10.1016/j.system.2014.07.008.

[49] C. Cavanagh, "The role of English in global citizenship global citizenship," J. Glob. Citizsh. Equity Educ., vol. 7, no. 1, pp. 1-23, 2020.

[50] E. Kenyon and A. Christoff, "Global citizenship education through global children's literature: An analysis of the NCSS Notable Trade Books," J. Soc. Stud. Res., vol. 44, no. 4, pp. 397-408, 2020, doi: https://doi.org/10.1016/j.jssr.2020.05.001.

[51] H.-L. Nguyen, V.-H. Dinh, P.-H. Hoang, V.-T. Luong, and A.-V. Le, "School students' perception, attitudes and skills regarding global citizenship-dataset from Vietnam," Data Br., vol. 37, p. 107162, 2021, doi: https://doi.org/10.1016/j.dib.2021.107162.

[52] M. Takkac and A. S. Akdemir, "Training Future Members of the World with an Understanding of Global Citizenship," Procedia - Soc. Behav. Sci., vol. 47, pp. 881-885, 2012, doi: https://doi.org/10.1016/j.sbspro.2012.06.751.

[53] S. A. Gani, Y. Q. Yusuf, and R. Susiani, "Progressive outcomes of collaborative strategic reading to EFL learners," Kasetsart J. Soc. Sci., vol. 37, no. 3, pp. 144-149, 2016, doi: https://doi.org/10.1016/j.kjss.2016.08.004. 
[54] L. A. A. Hamed, B. Behnam, and M. Saiedi, "The Role of Formal Schemata in the Development of Précis Writing in an Iranian EFL Context," Procedia - Soc. Behav. Sci., vol. 98, pp. 207-211, 2014, doi: https://doi.org/10.1016/j.sbspro.2014.03.408.

[55] C. C. M. Sung, "English as a lingua franca and global identities: Perspectives from four second language learners of English in Hong Kong," Linguist. Educ., vol. 26, pp. 31-39, 2014, doi: https://doi.org/10.1016/j.linged.2014.01.010.

[56] V. M. Smokotin, A. S. Alekseyenko, and G. I. Petrova, "The Phenomenon of Linguistic Globalization: English as the Global Lingua Franca (EGLF),” Procedia - Soc. Behav. Sci., vol. 154, no. October, pp. 509-513, 2014, doi: 10.1016/j.sbspro.2014.10.177.

[57] I. E. Allen and J. Seaman, Changing Course: Ten Years of Tracking Online Education in the United States. Boston: Babson Survey Research Group and Quahog Research Group, 2013.

[58] F. Mahini, Z. J.-A. Forushan, and F. Haghani, "The Importance of Teacher's Role in TechnologyBased Education," Procedia - Soc. Behav. Sci., vol. 46, pp. 1614-1618, 2012, doi: 10.1016/j.sbspro.2012.05.348.

[59] O. B. Azubuike, O. Adegboye, and H. Quadri, "Who gets to learn in a pandemic? Exploring the digital divide in remote learning during the COVID-19 pandemic in Nigeria," Int. J. Educ. Res. Open, p. 100022, 2020, doi: https://doi.org/10.1016/j.ijedro.2020.100022.

[60] M. Al-Amin, A. Al Zubayer, B. Deb, and M. Hasan, "Status of tertiary level online class in Bangladesh: students' response on preparedness, participation and classroom activities," Heliyon, vol. 7, no. 1, p. e05943, 2021, doi: https://doi.org/10.1016/j.heliyon.2021.e05943.

[61] R. Cakır and E. Solak, "Attitude of Turkish EFL Learners towards e-Learning through Tam Model," Procedia - Soc. Behav. Sci., vol. 176, pp. 596-601, 2015, doi: https://doi.org/10.1016/j.sbspro.2015.01.515.

[62] H.-H. Chung, S.-C. Chen, and M.-H. Kuo, “A Study of EFL College Students' Acceptance of Mobile Learning," Procedia - Soc. Behav. Sci., vol. 176, pp. 333-339, 2015, doi: https://doi.org/10.1016/j.sbspro.2015.01.479.

[63] T. Köse, E. ÿimen, and E. Mede, "Perceptions of EFL Learners about Using an Online Tool for Vocabulary Learning in EFL Classrooms: A Pilot Project in Turkey," Procedia - Soc. Behav. Sci., vol. 232, pp. 362-372, 2016, doi: https://doi.org/10.1016/j.sbspro.2016.10.051.

[64] H. A. Saed, A. S. Haider, S. Al-Salman, and R. F. Hussein, "The use of YouTube in developing the speaking skills of Jordanian EFL university students," Heliyon, vol. 7, no. 7, p. e07543, 2021, doi: https://doi.org/10.1016/j.heliyon.2021.e07543.

[65] P. Hercik, E. Milkova, and D. El-Hmoudova, "Language Skills Development in E-learning Language Courses," Procedia - Soc. Behav. Sci., vol. 182, pp. 653-659, 2015, doi: https://doi.org/10.1016/j.sbspro.2015.04.803.

[66] M. Gluchmanova, "Application of e-Learning in Foreign Language Teaching at the Technical University," Procedia - Soc. Behav. Sci., vol. 174, pp. 3144-3149, 2015, doi: 10.1016/j.sbspro.2015.01.1053.

[67] I. Rymanova, N. Baryshnikov, and A. Grishaeva, "E-course Based on the LMS Moodle for English Language Teaching: Development and Implementation of Results," Procedia - Soc. Behav. Sci., vol. 206, no. November, pp. 236-240, 2015, doi: 10.1016/j.sbspro.2015.10.016.

[68] G. Lawrence, F. Ahmed, C. Cole, and K. P. Johnston, "Not More Technology but More Effective Technology: Examining the State of Technology Integration in EAP Programmes," RELC J., vol. 51, no. 1, pp. 101-116, Apr. 2020, doi: 10.1177/0033688220907199.

[69] M. Sailer et al., "Technology-related teaching skills and attitudes: Validation of a scenario-based self-assessment instrument for teachers," Comput. Human Behav., vol. 115, p. 106625, 2021, doi: https://doi.org/10.1016/j.chb.2020.106625.

[70] A. Y. Alsabawy, A. Cater-Steel, and J. Soar, "IT infrastructure services as a requirement for elearning system success,” Comput. Educ., vol. 69, pp. 431-451, 2013, doi: https://doi.org/10.1016/j.compedu.2013.07.035.

J. C. Wiziack and V. M. P. D. dos Santos, "Evaluating an integrated cognitive competencies model to enhance teachers' application of technology in large-scale educational contexts," Heliyon, vol. 7, no. 1, p. e05928, 2021, doi: https://doi.org/10.1016/j.heliyon.2021.e05928. 